\title{
The competence of a teacher in the field of preschool legal education as an important component of professional competence
}

\author{
G.A. Paputkova ${ }^{1 *}, I . B$. Bicheva $^{2}$, and S.N. Kaznacheeva ${ }^{3}$ \\ ${ }^{1}$ K. Minin Nizhny Novgorod State Pedagogical University, Nizhny Novgorod, Russia \\ ${ }^{2}$ K. Minin Nizhny Novgorod State Pedagogical University, Nizhny Novgorod, Russia \\ ${ }^{3}$ K. Minin Nizhny Novgorod State Pedagogical University, Nizhny Novgorod, Russia
}

\begin{abstract}
The article discusses the relevance of the development of the teacher's competence in solving the problems of preschool legal education. The necessity to develop the competence of teachers in the field of preschool legal education is justified by the importance of implementing the requirements determined by the Federal State Educational Standard of Preschool Education in the field of legal education and social training of the child. The authors determined the structure of the teachers' competence in the field of preschool legal education, presented the characteristics of the components, described the levels of their formation. A model for the development of the teacher's competence in the field of preschool legal education is proposed, the pedagogical conditions for its implementation are disclosed. There are examples of the recommended forms and methods for the development of the teacher's competence in the field of preschool legal education which can be implemented in a preschool educational organization.
\end{abstract}

\section{A problem statement}

The development of the modern system of preschool education dictates special requirements for the professional teacher's competence as a condition for the implementation of strategic directions in the activities of preschool educational organizations and improving the quality of educational work with children $[1,2,3]$. In a situation when values are transformed and the Federal State Educational Standard of Preschool Education is presented the importance of legal education and social training of the child increases, and that requires the teacher to possess the legal basis for the implementation of professional activities, to develop the ability to select the content and technology to make children be aware of legal issues. The considered theses determine the study of the problem of teachers' competence in the field of preschool legal education as a structural element of professional competence and the conditions for its development as a continuous process of education / self-education $[4,5,6,7]$.

\footnotetext{
*Corresponding author: ipcs-profped@yandex.ru
} 


\subsection{The objective of the work}

The theoretical understanding of the problem considering the development of the legal competence of an individual is based on research substantiating its methodological, scientific-psychological and methodological foundations [8-10]. The analysis of scientific publications shows that the concept of "legal competence of a teacher" reveals as a personal and professional characteristics, manifested in the knowledge of legal norms and the willingness to follow them in professional activities, in the formation of legal values and the presence of a legal (civil) position.

We should note the works of I.P. Andriadi [11], T.A. Mantsurova [12] who study professional norms and the development of teacher's professional responsibility.

In the system of preschool education the importance of the problem in question is due to the relevance of the transformations, in accordance with which high requirements concerning the teacher's professional activity are imposed [13-15]. On the one hand, preschool legal education is not a separate educational area in the activities of a teacher. However, knowledge of the legal foundations of education and training, the ability to apply them, legal culture and lawful behavior of a teacher provide a normative impact on the child.

Therefore, the importance of preparing a child for the modern socio-cultural situation, the problem of protecting his rights is considered as a significant direction, which involves the solution of a whole range of tasks in the conditions of a preschool educational organization. At the same time, as the practice of preschool educational organizations shows, there is lack of sufficient attention to make children be aware of the law's basics, since teachers find it difficult to choose its content and studies' technologies [13]. In this regard, it is important to highlight the competence of teachers in the field of preschool legal education as a significant one in the general structure of professional competence.

\section{Materials and the results of the research}

The purpose of this article is to develop a model for the development of the teacher's competence in the field of preschool legal education.

Objectives:

- to determine the structure of the teacher's competence in the field of preschool legal education;

- to substantiate a model for the development of the teacher's competence in the field of preschool legal education;

- to reveal the pedagogical conditions for the implementation of the model in the conditions of a preschool educational organization.

Having considered the theoretical aspects of the problem of developing the teacher's competence in the field of preschool legal education, we should consider the definition of its structure and features of the model's development.

We define the teacher's competence in the field of preschool legal education as a complex of components, the formation of which will allow to organize the working process concerning the legal education of pupils, including in the field of civic education, in the most effective way[16]. The structure and content of the components of the teacher's competence in the field of preschool legal education is presented in Table 1. 
Table 1. Competence of a teacher in the field of preschool legal education.

\begin{tabular}{|l|l|}
\hline $\begin{array}{l}\text { Structural components of the } \\
\text { teacher`s competence in the field } \\
\text { of preschool legal education }\end{array}$ & Component characteristics \\
\hline Value-motivational & $\begin{array}{l}\text { Awareness of the legal position in the implementation of } \\
\text { laws, norms of society, profession. }\end{array}$ \\
$\begin{array}{l}\text { Focus on achieving a high-quality result of legal self- } \\
\text { development. } \\
\text { Installation on moral and legal activity and moral and legal } \\
\text { behavior. }\end{array}$ \\
\hline Content and legal & $\begin{array}{l}\text { Necessary and sufficient level of legal knowledge, ideas. } \\
\text { Knowledge management in the field of formation of legal } \\
\text { ideas among preschoolers Legal education, good breeding, } \\
\text { responsibility. Moral ethics Perception, understanding and } \\
\text { application of legal knowledge. }\end{array}$ \\
\hline Functional and active & $\begin{array}{l}\text { Experience of legal (lawful) behavior and activities. } \\
\text { Fulfillment of duties, self-regulation. } \\
\text { Respectful, friendly relationship and communication. }\end{array}$ \\
\hline Reflexive-evaluative & $\begin{array}{l}\text { Emotional involvement in the process of legal education. } \\
\text { Objectivity in assessing actions, behavior (one's own, } \\
\text { others). } \\
\text { Awareness of one's own legal position, professional legal } \\
\text { knowledge and methods of professional and legal } \\
\text { behavior. }\end{array}$ \\
\hline
\end{tabular}

The development of the components of the teacher's competence in the field of preschool legal education that we have identified will provide "the formation of legal interests, the holistic mastery of the norms of professional and legal culture, the development of legal worldview and self-awareness, legal regulation of professional relations, professional legal education, legal behavior" [7, p. 34].

Assessment of the formation of the teacher's competence in the field of preschool legal education supposes three levels: high, medium, low.

High level: a stable professional and legal position has been formed; conscious understanding of the value of legitimate professional activity; awareness of the meaning of legal self-knowledge; respectful attitude to law and legal relations as a norm of life. The high level provides systematic mastering the basic theoretical theses and substantive foundations of law, legal norms; mastering various methods of searching for legal information, its transformation in work with children and parents; mastering innovative methods of educational influence and interaction. A positive experience of legal behavior has been formed; continuous implementation of professional activities in accordance with legal regulations; possession of various methods of analyzing the educational (upbringing) situation from the position of its legitimacy; possession of various methods of protecting oneself, pupils, parents.

Medium level: the formation of the professional and legal position is not stable; the conscious understanding of the value of legitimate professional activity is not sufficiently manifested; the meaning of legal self-knowledge is not sufficiently understood; respect for law and legal relations is not constantly manifested. Fragmented mastering of the basic theoretical provisions and substantive foundations of law and legal norms is typical for the medium level; possession of some methods of searching for legal information, difficulties in transforming it in work with children and parents; possession of some methods of educational influence and interaction.

The experience of legal behavior does not appear regularly, mainly in familiar situations. It is typical not to constantly implement professional activities in accordance 
with legal norms; possession of some methods of analyzing the educational (upbringing) situation from the position of its legitimacy; possession of some methods of protecting oneself, pupils, parents.

Low level: legal position is not formed; the values of legitimate professional activity are not recognized or accepted; the meaning of legal self-knowledge is not realized; respect for law and legal relations is rarely or not shown.

Partial mastering of basic theoretical provisions and substantive foundations of law and legal norms is typical; partial possession of methods of searching for legal information, absence of the ability to transform it in work with children and parents; partial mastery of methods of educational influence and interaction. The experience of legal behavior is not formed; implementation of professional activities in accordance with legal norms is difficult. Partial mastery of the methods of analysis of the educational (upbringing) situation from the position of its legitimacy is typical; partial possession of methods of protecting oneself, pupils, parents.

The considered provisions determine the elaboration of a model for the development of the teacher's competence in the field of preschool legal education, adapted to the logic, content of innovative development of preschool education and due to the influence of external and internal factors of professional and legal activity (Figure 1).

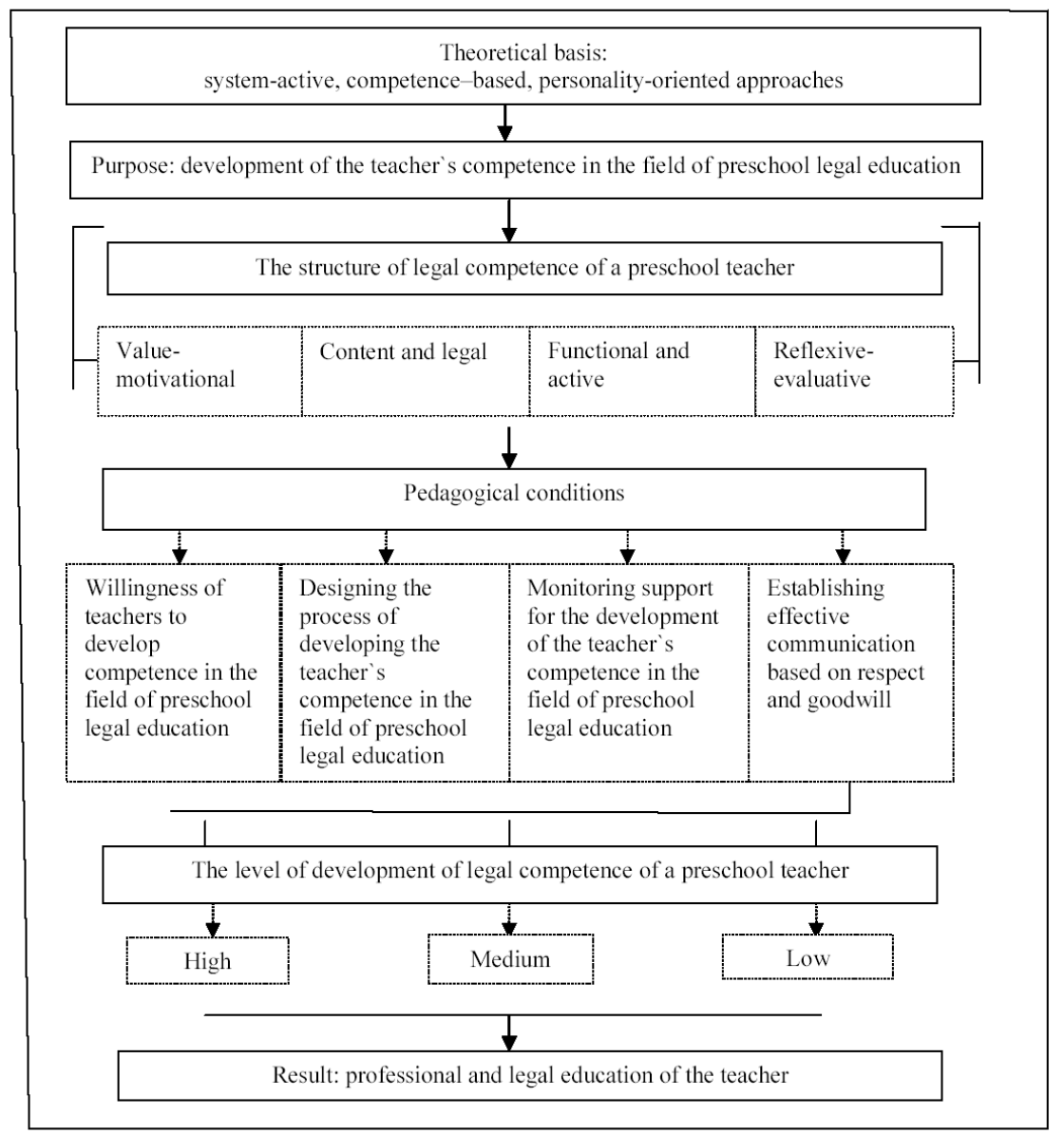

Fig. 1. Model of development of the teacher's competence in the field of preschool legal education. 
The methodologies of the system-activity, personality-oriented and competence-based approaches are considered to be the theoretical basis for the development of the teacher's competence in the field of preschool legal education is. This made it possible to distinguish the key principles of its development:

- the principle of consistency and continuity of self-education and methodological support of teachers to master the necessary scientific, theoretical and practice-oriented knowledge;

- the principle of self-organization and self-regulation in achieving the goals set on the basis of regulatory requirements;

- the principle of the teacher's personal responsibility for the result of the development of competence in the field of preschool legal education;

- the principle of taking into account the individual capabilities and achievements of teachers in professional self-expression and self-presentation of professional success;

- the principle of constructive interaction in the process of methodological support;

- the principle of voluntariness, freedom and awareness while choosing forms of interaction (joint activities);

- the principle of differentiated selection of content, forms and methods of developing the teacher's competence teachers in the field of preschool legal education.

In accordance with the proposed model for the development of teacher's competence in the field of preschool legal education, pedagogical conditions for its implementation are proposed.

The first condition is the willingness of teachers to develop competence in the field of preschool legal education:

- awareness of professional and cultural norms of professional activity;

- understanding of their rights and obligations as the main way of regulating professional relations;

- motivation for independent mastery of knowledge, their creative refraction in the practice of professional activity, respect for professional experience.

The second condition is designing the process of developing the teacher's competence in the field of preschool legal education:

- determination of the current legal content, the choice of effective innovative forms and methods of its development in jointly organized methodological events;

- development of individually-oriented content, forms, methods of methodological support for the development of competence in the field of preschool legal education in accordance with the capabilities and problems of a particular teacher.

The third condition is monitoring support for the development of the teacher's competence in the field of preschool legal education:

- creation of a set of diagnostic techniques for teachers (and parents) to study the level of formation of the components of competence in the field of preschool legal education and for children of senior preschool age in order to study the level of formation of ideas about law;

- study of the real level of formation of the teacher's competence in the field of preschool legal education for the subsequent concretization of the individual goals of its development (identification of problems and "points of growth").

The fourth condition is the establishment of effective communication and cooperation in the process of methodological support:

- creation of the atmosphere of respect and goodwill, consistency of positions, professional decisions through informational and communicative, open to question, interactive, problem-searching forms of methodological support [17].

In the conditions of a preschool educational organization the implementation of these conditions is ensured through methodological support, including active forms and methods 
of work [18-25]. Examples of recommended forms and methods for the development of the legal competence of teachers are given in Table 2.

Table 2. Examples of forms and methods for the development of the legal competence of teachers in the conditions of a preschool educational organization.

\begin{tabular}{|l|l|}
\hline \multicolumn{1}{|c|}{ Conditions } & \multicolumn{1}{|c|}{ Examples of recommended forms and methods } \\
\hline \multicolumn{1}{|c|}{ 1 } & \multicolumn{1}{|c|}{ 2 } \\
\hline $\begin{array}{l}\text { 1. Willingness of teachers to } \\
\text { develop competence in the } \\
\text { education preschool legal }\end{array}$ & $\begin{array}{l}\text { Controversy "Legal culture is ..." } \\
\text { Discussion "Why do we need legal education?" } \\
\text { Workshop "Can I improve my legal competence?" } \\
\text { Reflexive exercise "Legal relationships are ..." }\end{array}$ \\
\hline $\begin{array}{l}\text { 2. Designing the process of } \\
\text { developing competence in } \\
\text { the field of preschool legal } \\
\text { education }\end{array}$ & $\begin{array}{l}\text { Methodical seminar "Content of legal education of a preschooler" } \\
\text { Consultation "Requirements for planning work on the legal } \\
\text { education of preschoolers" } \\
\text { Workshop "Design of the informational and legal environment of } \\
\text { preschool education organization" } \\
\text { Drawing up a methodological resource bank on the legal } \\
\text { education of a child } \\
\text { Development of abstracts of educational events based on the } \\
\text { pages of the Convention on the Rights of the Child }\end{array}$ \\
\hline $\begin{array}{l}\text { 3. Monitoring support for } \\
\text { development of } \\
\text { competence in the field of } \\
\text { preschool legal education }\end{array}$ & $\begin{array}{l}\text { Studying of the real level of development of the teacher's } \\
\text { competence in the field of preschool legal education } \\
\text { (questionnaires, problem assignments, etc.) } \\
\text { Identifying problems and prospects } \\
\text { Studying the level of formation of ideas about law of older } \\
\text { preschool children } \\
\text { Intellectual game "Law experts" }\end{array}$ \\
\hline $\begin{array}{l}\text { E. Establishing effective } \\
\text { communication and } \\
\text { cooperation in the process } \\
\text { of methodological support }\end{array}$ & $\begin{array}{l}\text { Round table "Legal interaction: problems and prospects" } \\
\text { Training "Communication between us" } \\
\text { Reflexive seminar "Rights and obligations" }\end{array}$ \\
\hline
\end{tabular}

The result of the development of the teacher's competence in the field of preschool legal education is their professional and legal education, which can be determined by the following characteristics:

- understanding the importance of legal values and the system of legal relationships for professional activities,

- high interest in legal self-education, self-education and study of the features of legal education of preschool children;

- knowledge and implementation of legal norms in professional activity, taking into account general pedagogical laws and trends;

- critical and objective analysis of the legitimacy of their professional activities` implementation, the ability to take responsibility for the decisions made;

- the formation and manifestation of such personal qualities as justice, humanity, objectivity, etc.

\section{Conclusions}

Studying the problem of developing the teacher`s competence in the field of preschool legal education leads to the following conclusions:

- firstly, the competence of teachers in the field of preschool legal education is an important component of professional competence, which ensures the integrity of the process of legal education and development of a child in the general system of upbringing and educational work; 
- secondly, the achievement of the necessary level of development of competence by teachers in the field of preschool legal education will ensure the purposeful introduction of children to legal values, the manifestation of their legal activity and culture, the acquisition of initial ideas about the rights and obligations of a person, experience of moral and legal behavior in the process of interaction with peers and adults. Consequently, the high level of its formation must be considered as the basis for the formation of the legal competence of pupils.

The prospect of further research involves testing a model for the development of the teacher`s competence in the field of preschool legal education and testing the pedagogical conditions for its implementation in a preschool educational organization.

\section{References}

1. A.A. Mayer, Development strategy of modern of the preschool educational, Nizhegorodskoe obrazovanie, 3, 18-22 (2015)

2. N.V. Belinova, I.B. Bicheva, A.Y. Vershinina, T.G. Khanova, A.V. Khizhnaya, Innovation and education: technologies and perspectives, Journal of Advanced Research in Dynamical and Control Systems, 12 (4), 1307-1313 (2020)

3. I.B. Bicheva, S.N. Kaznacheeva, Development of professional competence of pedagogical education specialists in building a career, Science and practice of regions, 1 (14), 63-66 (2019)

4. A.S. Kindyashova, N.R. Volkova, Legal competence as a structural element of teacher competence, Modern problems of science and education, 6, 151 (2017)

5. E.G. Matvievskaya, A.A. Muratova, Continuous education of preschool teachers, Bulletin of the Chelyabinsk State Pedagogical University, 9, 83-88 (2016)

6. G.A. Paputkova, Competence-based approach and practice-oriented education, Education and Science. Izvestiya URO RAO, 1, 9 (2008)

7. I.B. Bicheva, T.G. Khanova, P.Y. Potanina, N.Y. Gladkova, Features of the formation of legal competence of the future teacher of preschool education, International Journal of Experimental Education, 5, 32-35 (2017)

8. A.S. Anikina, P.G. Postnikov, Legal competence as a planned result of a teacher's professional training, Pedagogical education and science, 2, 24-28 (2012)

9. A.V. Korotun, S.I. Glukhikh, Formation of the legal competence of future social educators, Pedagogical education and science, 10, 96-99 (2008)

10. A.V. Pozdnyakov, Modular technologies for the formation of the teacher's normative and legal competence, Psychological and pedagogical journal Gaudeamus, 1 (17), 5659 (2011)

11. I.P. Andriadi, Professional standards and professional responsibility of the teacher, Pedagogical education and science, 4, 46-48 (2010)

12. T.A. Mantsurova, Conditions for the development of professional responsibility of a social teacher, Fundamental research, 2, 66-68 (2007)

13. I.B. Bicheva, N.E. Gladkova, The relevance of legal education in a preschool educational organization, Prospects for Science and Education, 5 (29), 45-49 (2017)

14. S.A. Laryushkin, T.A. Svatalova, Cognitive aspect of the legal competence of preschool teachers, formed in the system of additional professional education, Scientific support of the system of advanced training of personnel, 1 (26), 40-45 (2016) 
15. S.A. Martynova, The concept and specificity of the legal competence of teachers of a preschool educational organization, Bulletin of Science and Education, 9-1 (87), 7779 (2020)

16. I.B. Bicheva, A.V. Bikeeva, Features of civic education in preschool children, Science and practice of regions, 4 (17), 53-57 (2019)

17. O.I. Vaganova, L.V. Tsyganova, E.A. Chelnokova, A.V. Lapshova, L.A. Turchina, Technology «Debate» as a tool for communicative competence development, Amazonia Investiga, 9 (27), 367-375 (2020)

18. S.F. Bagautdinova, Features of methodical work in a modern preschool educational institution, Management of preschool educational institution, 3, 82-85 (2010)

19. V.P. Larina, Organization of scientific and methodological support of innovative activities of educational institutions, Scientific research in education, 6, 27-29 (2008)

20. A.A. Mayer, Technologies for training a preschool teacher for innovative activities. Research and Development, Social and humanitarian research and technology, 5 (2), 3-6 (2016)

21. O.I. Vaganova, Z.V. Smirnova, S.N. Kaznacheeva, L.I. Kutepova, M.M. Kutepov, Practically-Oriented Technologies in Professional Education, Lecture Notes in Networks and Systems, 73, 433-439 (2020)

22. Z.V. Smirnova, M.V. Mukhina, O.V. Katkova, M.L. Gruzdeva, O.T. Chernei, Network Interaction as a Factor of Professional Qualities' Development of Service Workers, Lecture Notes in Networks and Systems, 87, 698-704 (2020)

23. E.A. Sidyakina, I.S. Lysakova, Management of scientific and methodological work of teachers in a preschool educational organization through the development of projects, Scientific reflection, 1 (1), 39-41 (2016)

24. E.V. Starodubtseva, Consulting support of teachers' innovative activity as a factor of professional development, Education and self-development, 5 (27), $42-47$ (2011)

25. T.G. Khanova, N.V. Belinova, Continuing education of preschool teachers: methodological support for improving professional competence, Problems of modern pedagogical education, 67-3, 240-243 (2020) 